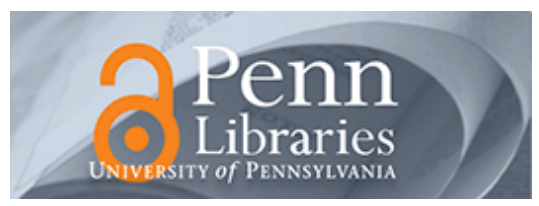

University of Pennsylvania ScholarlyCommons

January 2003

\title{
Community and population dynamics of spruce-fir forests on Whiteface Mountain, New York: recent trends, 1985-2000
}

John J. Battles

University of California, Berkeley

Timothy J. Fahey

Cornell University

Thomas G. Siccama

Yale University

Arthur $\mathrm{H}$. Johnson

University of Pennsylvania, ahj@sas.upenn.edu

Follow this and additional works at: https://repository.upenn.edu/ees_papers

\section{Recommended Citation}

Battles, J. J., Fahey, T. J., Siccama, T. G., \& Johnson, A. H. (2003). Community and population dynamics of spruce-fir forests on Whiteface Mountain, New York: recent trends, 1985-2000. Retrieved from https://repository.upenn.edu/ees_papers/11

Copyright NRC Research Press. Published in Canadian Journal of Forest Research, Volume 33, Number 1, January 2003, pages 54-63.

Publisher URL: http://pubs.nrc-cnrc.gc.ca

This paper is posted at ScholarlyCommons. https://repository.upenn.edu/ees_papers/11

For more information, please contact repository@pobox.upenn.edu. 


\title{
Community and population dynamics of spruce-fir forests on Whiteface Mountain, New York: recent trends, 1985-2000
}

\begin{abstract}
We remeasured two sets of permanent plots in old-growth, spruce-fir forests on Whiteface Mountain to quantify ongoing vegetation dynamics at sites impacted by spruce decline. One set of plots was a stratified random sample of the vegetation in a subalpine watershed (Baldwin site). The other was selected to represent forest conditions in a high-elevation subset of the spruce-fir forest (Esther site). Between 1987 and 1997, there was a significant increase in aboveground tree biomass at Baldwin with the majority of the increment due to the growth of canopy-sized trees. This growth occurred with little change in either species composition or size structure. The annual mortality rate of $1.2 \% \cdot \mathrm{year}^{-1} \mathrm{for}$ canopy-sized red spruce (Picea rubens Sarg.) in Baldwin almost matched the recruitment rate of 1.4 stems/ha per year. In addition, the relative growth rate of spruce was significantly faster than associated species. In contrast, spruce trees in Esther died at a rate of the $3.6 \% \cdot$ year $^{-1}$ (1985-1995), and survivors grew more slowly than other species. The most obvious community-level trend at Esther (1985-2000) was an increase in overall tree density with most of this increase due to ingrowth of small trees. The demography of the spruce population at Baldwin suggests that the decline is over for at least this population.
\end{abstract}

\section{Comments}

Copyright NRC Research Press. Published in Canadian Journal of Forest Research, Volume 33, Number 1, January 2003, pages 54-63.

Publisher URL: http://pubs.nrc-cnrc.gc.ca 


\title{
Community and population dynamics of spruce-fir forests on Whiteface Mountain, New York: recent trends, 1985-2000
}

\author{
John J. Battles, Timothy J. Fahey, Thomas G. Siccama, and Arthur H. Johnson
}

\begin{abstract}
We remeasured two sets of permanent plots in old-growth, spruce-fir forests on Whiteface Mountain to quantify ongoing vegetation dynamics at sites impacted by spruce decline. One set of plots was a stratified random sample of the vegetation in a subalpine watershed (Baldwin site). The other was selected to represent forest conditions in a high-elevation subset of the spruce-fir forest (Esther site). Between 1987 and 1997, there was a significant increase in aboveground tree biomass at Baldwin with the majority of the increment due to the growth of canopy-sized trees. This growth occurred with little change in either species composition or size structure. The annual mortality rate of $1.2 \%$ year $^{-1}$ for canopy-sized red spruce (Picea rubens Sarg.) in Baldwin almost matched the recruitment rate of $1.4 \mathrm{stems} / \mathrm{ha}$ per year. In addition, the relative growth rate of spruce was significantly faster than associated species. In contrast, spruce trees in Esther died at a rate of the 3.6\% year $^{-1}$ (1985-1995), and survivors grew more slowly than other species. The most obvious community-level trend at Esther (1985-2000) was an increase in overall tree density with most of this increase due to ingrowth of small trees. The demography of the spruce population at Baldwin suggests that the decline is over for at least this population.

Résumé : Nous avons remesuré deux groupes de parcelles permanentes dans de vieilles forêts de sapin et épinette du mont Whiteface pour quantifier la dynamique actuelle de la végétation dans des stations affectées par le dépérissement de l'épinette. Un premier groupe de parcelles constituait un échantillonnage aléatoire stratifié de la végétation dans un bassin versant subalpin (la station Baldwin). L'autre groupe de parcelles avait été choisi de manière à représenter les conditions de la forêt dans un sous-ensemble à haute altitude de la forêt de sapin et épinette (la station Esther). Entre 1987 et 1997, il y a eu une augmentation significative de la biomasse épigée des arbres dans la station Baldwin où la majeure partie de l'accroissement est due à la croissance des arbres formant le couvert. Cette croissance s'est produite avec peu de changements dans la composition en espèces, ni dans la structure dimensionnelle. Le taux annuel de mortalité de $1,2 \% \cdot \mathrm{an}^{-1}$ pour l'épinette rouge (Picea rubens Sarg.) présente dans le couvert de la station Baldwin correspond à peu de chose près au taux de recrutement de 1,4 tiges/ha par an. De plus, le taux relatif de croissance de l'épinette est significativement plus élevé que celui des autres essences auxquelles cette essence est associée. Par

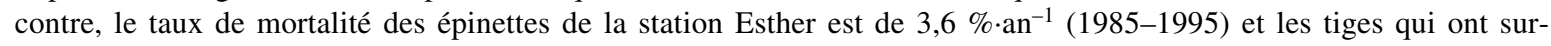
vécu ont crû plus lentement que les autres espèces. La tendance la plus évidente observée à l'échelle de la communauté dans la station Esther (1985-2000) est une augmentation générale de la densité des arbres où la majeure partie de l'augmentation est due au recrutement de petits arbres. La démographie de la population d'épinette à la station Baldwin porte à croire que le dépérissement est terminé, au moins dans cette population.
\end{abstract}

[Traduit par la Rédaction]

\section{Introduction}

The decline of red spruce (Picea rubens Sarg.) trees in the northeastern United States is a well-documented example of the negative impact chronic atmospheric pollution, specifically acid deposition, can have on the terrestrial biota

Received 4 October 2001. Accepted 3 September 2002.

Published on the NRC Research Press Web site at

http://cjfr.nrc.ca on 16 December 2002.

J.J. Battles. ${ }^{1}$ University of California, Berkeley, CA 94720,

U.S.A.

T.J. Fahey. Cornell University, Ithaca, NY 14853, U.S.A

T.G. Siccama. Yale University, New Haven, CT 06511,

U.S.A.

A.H. Johnson. University of Pennsylvania, Philadelphia,

PA 19104, U.S.A.

${ }^{1}$ Corresponding author (e-mail: jbattles@ nature.berkeley.edu).
(Driscoll et al. 2001). Red spruce is a common tree in the upland forests in the northeastern United States. It occurs across a biome transition from eastern deciduous forest to conifer forest (Bormann et al. 1970). Beginning in the mid1960s, many overstory red spruce trees in the region experienced a progressive loss of vigor. Symptoms included both crown dieback and reduced radial growth rates (Johnson and Siccama 1983). By the 1980 s, as many as half the standing spruce trees were dead in some high-elevation stands (Siccama et al. 1982; Scott et al. 1984; Battles et al. 1992).

The decline has been directly linked to freezing injury of spruce foliage (Friedland et al. 1984; Johnson et al. 1988; Peart et al. 1992b; Tobi et al. 1995). There is good evidence from both laboratory studies (DeHayes et al. 1999) and field trials (Vann et al. 1992) that exposure to acidic cloud water reduces the freezing tolerance of spruce leaves. In addition, chronic acid input has depleted calcium supplies (Likens et al. 1996) and mobilized additional aluminum (Shortle and 
Smith 1988) in northeastern U.S. forest soils. These changes in soil quality can adversely affect the growth of red spruce trees (Cronan and Grigal 1995). Also spruce-fir forests at high elevation are thought to be among the most sensitive ecosystems to nitrogen pollution. According to one scenario, the continuation of current levels of nitrogen deposition to these high-elevation forests could effect wholesale shifts in community composition with hardwood trees replacing the now-dominant conifer trees (McNulty et al. 1996; Fenn et al. 1998).

The regional trend in pollution shows a modest decline in one of the two primary constituents of acidic deposition. In the U.S. Northeast, the concentration of $\mathrm{SO}_{4}{ }^{2-}$ in precipitation has decreased significantly since 1970, while there has been no discernable change in the wet deposition of $\mathrm{N}$ (Likens et al. 2001; Driscoll et al. 2001). For example at the National Atmospheric Deposition Program's site on Whiteface Mountain, New York (610 m elevation), $\mathrm{SO}_{4}{ }^{2-}$ wet deposition has decreased by almost $4 \% \cdot$ year $^{-1}$ between 1985 and 2000 while for the same period there was no detectable trend in the rate of $\mathrm{N}$ deposition (data from National Atmospheric Deposition Program Web site). ${ }^{2}$ Coincident with these changes in acidic deposition, there is some indication that since the mid-1980s, red spruce at some sites may be recovering from the decline. Silver et al. (1991) reported large increases in dead spruce between 1982 and 1987 in their resurvey of stands on Whiteface Mountain, but noted an improvement in the crown condition of surviving trees. Several researchers have observed marked increases in spruce annual growth rates, as measured from increment cores, since the mid-1980s (Siccama et al. 1994a; Reams and Van Deusen 1995).

In this paper, we provide an update of the status of the subalpine forest community and red spruce populations at Whiteface Mountain, a sentinel site for environmental monitoring in northern New York. Our fundamental premise is that species declines and the role of anthropogenic disturbances must be evaluated in the context of the prevailing vegetation dynamics. Thus, a comprehensive review of the effects of acidic deposition on trees requires recent trends in forest composition and tree demography to complement measures of pollutant emission and deposition rates. We derived this key information from re-measurements of a subset of the permanent sample plots established in the 1980s for the explicit purpose of monitoring the course of spruce decline. Within this framework, we examined two questions: (i) what is the forest-wide implication of a population level phenomenon, such as red spruce decline, and (ii) are red spruce populations recovering from the recent episode of decline? We confined this initial investigation to two oldgrowth stands with a history of detailed ecological and biogeochemical studies. By doing so, we minimized the variability associated with differences in land-use history and capitalized on the wealth of associated data.

\section{Materials and methods}

Study site

Whiteface Mountain $\left(44^{\circ} 22^{\prime} \mathrm{N}, 73^{\circ} 54^{\prime} \mathrm{W}\right)$ and its four subpeaks form an isolated massif at the northern end of Adirondack Mountains of New York. The entire massif lies within the boundaries of Adirondack Forest Preserve and the land is managed by the New York State Department of Environmental Conservation. ${ }^{3}$ The Adirondacks are in a region of cool, wet summers and cold, snowy winters. Mean growing season temperatures (mid-May to mid-September) on Whiteface Mountain range from $11.3^{\circ} \mathrm{C}$ at the summit (1483 m elevation) to $17.8^{\circ} \mathrm{C}$ at $603 \mathrm{~m}$ elevation (Battles et al. 1992). The past 15 years have been warmer than the previous 20 years. Mean monthly winter temperatures (November-February) at the observatory on Whiteface Mountain (603 m elevation) averaged $0.5^{\circ} \mathrm{C}$ warmer in 1984-1999 than in 1964-1983 (D. Wolfe, Atmospheric Science Research Center, State University of New York, Albany, N.Y., personal communication). Mean annual precipitation at $1000 \mathrm{~m}$ elevation is $156 \mathrm{~cm}$, of which $30 \%$ falls as snow (Friedland and Miller 1999). Moderately deep to thin till covers the bedrock (primarily anorthosite). Soil type varies along the elevation gradient with a broad transition around $1150 \mathrm{~m}$ elevation between Spodosols below and Histosols above (Witty 1968).

\section{Data sources and background}

Between 1964 and 1966, one hundred and eighty-two forest stands on Whiteface Mountain were quantitatively sampled to examine vegetation-environment relations (Holway et al. 1969). These stands were not permanently marked, but their approximate locations are known from detailed field notes and maps. This original work documented that $(i)$ the vegetation of the Whiteface massif is representative of the regional montane flora and (ii) like other mountains in the northeastern United States, the spatial distribution of vegetation is organized along the elevational complex gradient (Cogbill and White 1991). Specifically at Whiteface Mountain, red spruce, balsam fir (Abies balsamea (L.) Mill.), and mountain paper birch (Betula papyrifera var. cordifolia (Regel.) Fern.) share dominance in the spruce-fir zone (800$1100 \mathrm{~m}$ in elevation). Yellow birch (Betula alleghaniensis Britt.) can be an important component at the lower end of the spruce-fir forest $(800-900 \mathrm{~m})$. Below $800 \mathrm{~m}$, conifers are gradually replaced by northern hardwood species. Above $1100 \mathrm{~m}$, balsam fir becomes increasingly important and forms almost pure stands between 1200 and $1350 \mathrm{~m}$ (Holway et al. 1969; Battles et al. 1992).

In 1982, Scott et al. (1984) relocated and resurveyed 32 of the subalpine stands at Whiteface Mountain and found a 40 $70 \%$ decrease in the basal area of spruce with the greatest decrease occurring in the high-elevation $(>900 \mathrm{~m})$ stands. Siccama et al. (1982) had earlier reported similar decreases in spruce basal area for a comparable forest in Vermont. These two studies provided the best evidence of a regionwide decline in spruce populations (Peart et al. 1992a).

In 1987, we completed a network of permanent sample plots in the subalpine forests $(700-1350 \mathrm{~m})$ on Whiteface Mountain as part of the U.S. Environmental Protection Agency (EPA) - USDA Forest Response Program (Battles et al. 1992). We placed the centre of a 21-transect grid at a randomly chosen point along the primary north-south ridge of

\footnotetext{
${ }^{2}$ National Atmospheric Deposition Program Web site: http://nadp.sws.uiuc.edu.

${ }^{3}$ New York Department of Environmental Conservation Web site: http://www.dec.state.ny.us/.
} 
Fig. 1. Topographic map of the long-term vegetation plots and research sites on Whiteface Mountain. Contour intervals are $50 \mathrm{~m}$. Grid lines are sample transects. The map was reproduced from 1978 U.S. Geological Survey 1:25000 scale metric maps of the Wilmington and Lake Placid quadrangles.

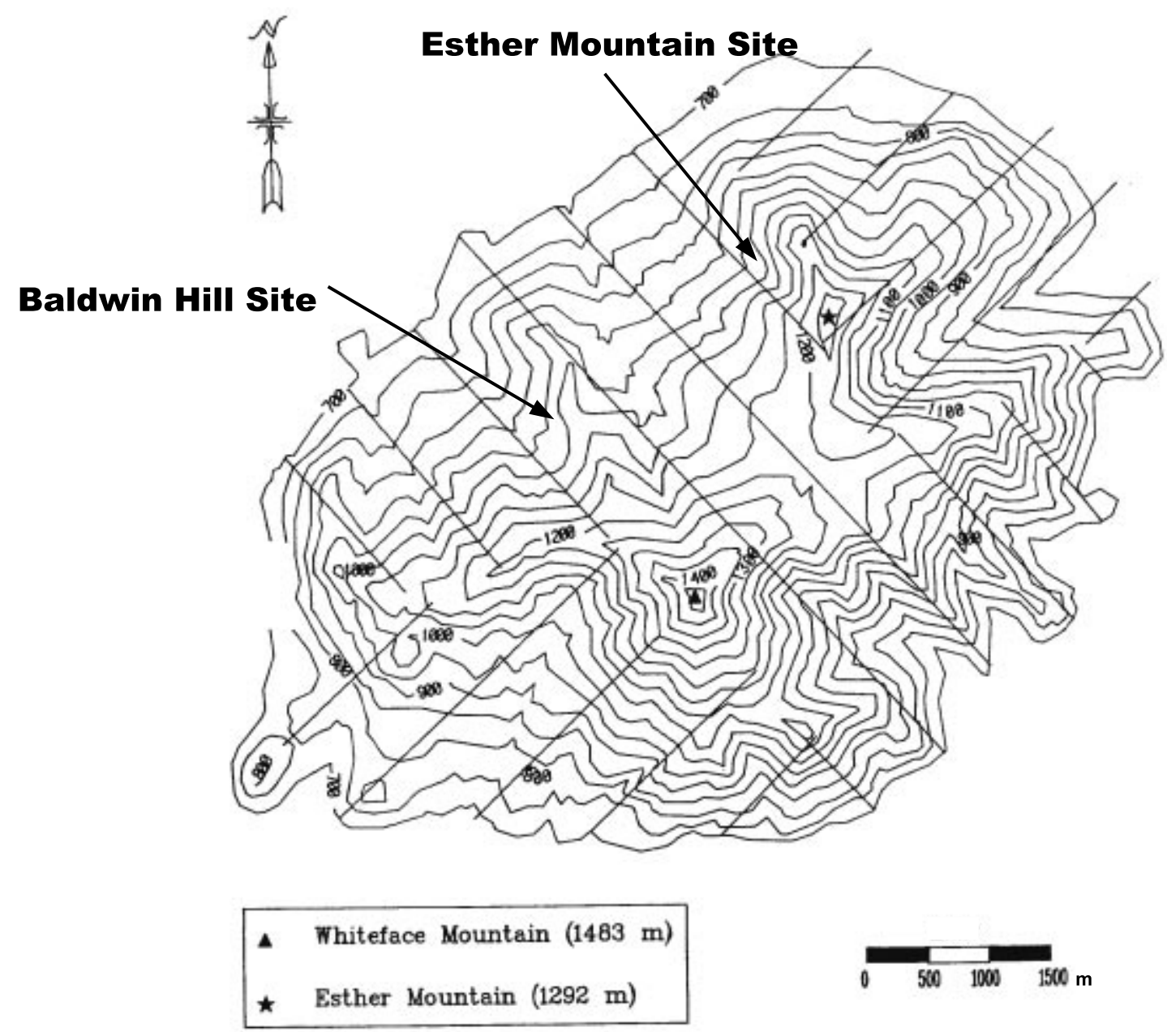

the Whiteface massif (Fig. 1). To track individual tree growth and population demography, 60 permanent plots (most $400 \mathrm{~m}^{2}$ in area) were located along the transects in a stratified random manner. Strata were defined to ensure sampling red spruce populations at different elevations and aspects. All trees $\geq 5 \mathrm{~cm}$ diameter at breast height (DBH, breast height $=1.37 \mathrm{~m}$ ) were tagged and identified. For tagged trees, DBH, canopy position, and vigor were recorded. Height and height to live crown were measured on a random subset of trees. Understory trees (trees $\geq 1 \mathrm{~m}$ tall and $<5 \mathrm{~cm} \mathrm{DBH}$ ) were measured and counted along $2 \mathrm{~m}$ wide transects that centered on the diagonals of the plot $\left(109 \mathrm{~m}^{2}\right)$.

In 1997, we measured all the permanent sample plots (11) that were located in the watershed southwest of Baldwin Hill (Fig. 1). At the Baldwin site, there is no historical or ecological evidence that the spruce-fir forest has ever been logged or burned (Battles and Fahey 2000). The plots were normally distributed across the elevation gradient with a mean elevation of $943 \mathrm{~m}$, near the midpoint of the elevation gradient that encompasses the spruce-fir forest $(800-1100 \mathrm{~m})$. The slope of the plots was $14 \pm 7^{\circ}$ (mean $\pm \mathrm{SD}$ ), and the Baldwin watershed was on the northwestern face of the mountain. In 1987, forty-three percent of the standing red spruce trees in the 11 remeasured plots were dead, and $15 \%$ of the forested area was affected by fine-scale, canopy gaps (Battles and Fahey 1996).

In 1985, an Integrated Forest Study site was established near Esther Mountain on the northwestern slope of Whiteface Mountain (Fig. 1). The primary objective was to analyze the effects of atmospheric deposition on nutrient cycling in a variety of forest ecosystems (Johnson and Lindberg 1992). The Esther site was located in a highelevation, old-growth, spruce-fir forest. Four 0.1-ha circular plots were set up to monitor vegetation influence on nutrient flux. In these plots we identified, measured, and tagged every woody stem $\geq 2 \mathrm{~cm}$ DBH. Plots were selected to represent the range of structural conditions observed in the spruce-fir forest (Friedland et al. 1991). These plots have been remeasured at least every 5 years since 1985 . However, since 1993 only canopy-sized trees $(\mathrm{DBH} \geq 9.5 \mathrm{~cm})$ were tracked individually, while the smaller trees in the plots were subsampled in five radial transects (total sample area = $178 \mathrm{~m}^{2}$ ). The Esther plots are at a mean elevation of $1031 \mathrm{~m}$ with a narrow range from 1000 to $1063 \mathrm{~m}$. The slope was $22 \pm 4^{\circ}$. In 1985 , forty-three percent of the standing red spruce trees in the Esther plots were dead. 
Neither site was seriously impacted by the destructive, regional ice storm of 1998 (Irland 1998). The ice storm struck the northeastern United States and southeastern Canada in January 1998 and caused damage to $1.86 \times 10^{6}$ ha in New York. On Whiteface Mountain, icing was confined to elevations below $830 \mathrm{~m}$ and to forests on the east side of the massif (New York Department of Environmental Conservation Web site; D. Wolfe personal communication).

\section{Data analysis}

We used these three data sources (Scott stands, Baldwin plots, and Esther plots) to assess change in the old-growth spruce-fir forests at two sites on Whiteface Mountain. Results from the Scott stands serve as a baseline description of the predecline forest. We took care to summarize the composition in 1964-1966 for stands in the same general area as the Baldwin and Esther sites. Following the ecological sampling standards of the time, Holway and Scott (1969) measured only stands without recent major disturbances. Thus, the 1964-1966 results represent only the mature phase of forest development.

From the repeated measures in the Esther and Baldwin plots, we calculated annual mortality, recruitment, and growth rates. We followed the methods in Sheil and May (1996) for evaluating mortality and recruitment and took care to avoid census-period dependence by making comparisons only over census intervals of the same length. Specifically annual mortality $\left(\lambda, \% \cdot\right.$ year $\left.^{-1}\right)$ and recruitment $(k$, individuals/ha per year) were computed as follows:

$$
\begin{aligned}
& \lambda=\frac{\ln \left(N_{0}\right)-\ln \left(N_{t}\right)}{t} \\
& k=-\frac{N^{*}}{A t} \ln \left[1-\frac{N_{\mathrm{r}}(t)}{N^{*}}\right]
\end{aligned}
$$

where $N_{t}$ is the number of live individuals at the end of the census interval, $N_{0}$ is the number of live individuals at the beginning of the census, $t$ is the length of the census interval, $A$ is the area sampled, and $N_{\mathrm{r}}(t)$ is the total number of new stems (recruits) present at the end of the census. To account for those individuals that are newly recruited but die before they can be recorded at the end of the census interval, we assumed that the 1964-1966 estimates of tree density were the asymptotic steady-state values to which the periodic recruitment rates tend ( $N^{*}$ in eq. 2 ). While any assumption of near steady-state dynamics is suspect for a forest recovering from a decline-disturbance (Battles and Fahey 1996), in practice our calculated recruitment rates were not sensitive to large changes in $N^{*}$. For example, a $50 \%$ decrease in $N^{*}$ for subcanopy spruce trees in Baldwin only raised the estimated recruitment rate by $12 \%$; doubling $N^{*}$ only decreased the recruitment estimate by $4 \%$.

We expressed individual tree growth as stem volume increment. To compare the growth rate among species and populations with different size structures, we needed a metric that accounted for the allometric scaling between plant growth and plant size (Enquist et al. 1999; Niklas and Enquist 2001). Based on inspection of the data, we chose to measure growth as the slope of the regression line describing stem volume increment as a linear function of initial stem volume. All regression were forced through zero to preserve biological reality (i.e., trees with no volume do not grow). Specifically, for each species at each site we fit the following equation using a least-squares procedure:

[3] $\quad V_{t}-V_{0}=\operatorname{RGI}_{\mathrm{v}}\left(V_{0}\right)$

where $\mathrm{RGI}_{\mathrm{v}}$ is the relative growth increment $\left(\mathrm{m}^{3} \cdot \mathrm{m}^{-3}\right), V_{t}$ is the stem volume at the end of the census interval, and $V_{0}$ is the stem volume at the beginning of the census interval. In all cases, the census interval was 10 years. For all regressions, there was a significant linear relationship between stem volume increment and initial stem volume $(p<0.01)$. The fits ranged from a high of $R^{2}=0.65$ for balsam fir at Esther to a low of $R^{2}=0.29$ for red spruce at Esther. Stem volume was computed using a parabolic approximation: onehalf the stem cross-sectional area at breast height times the tree height (Whittaker et al. 1974). Tree heights were estimated using site-specific allometric equations that predict height as a function of species, $\mathrm{DBH}$, and elevation (Battles et al. 1995).

Changes in aboveground tree biomass were assessed using the standard methodology described in Whittaker et al. (1974). For canopy-sized trees (trees $\geq 9.5 \mathrm{~cm} \mathrm{DBH),} \mathrm{we} \mathrm{es-}$ timated parabolic volume as described above and then used volume as the independent variable to predict tree biomass from the allometric equations in Whittaker et al. (1974) as updated by Siccama et al. (1994b). This approach is the same as that applied by Friedland et al. (1991) and Friedland and Miller (1999) for biogeochemical analyses at the Esther site. However, we used separate species-specific equations for trees smaller than $9.5 \mathrm{~cm} \mathrm{DBH}$ to account for ontogenetic change in tree allometry. A suite of equations for the dominant species at Whiteface Mountain were available from work done in the White Mountains of New Hampshire (Fahey et al. 1998; Reiners 1992; T. Siccama, unpublished data).

\section{Statistical analysis}

To assess changes in forest composition and tree biomass, we used the appropriate repeated-measures design where the subjects (in this case, the plots) serve as their own controls (Neter et al. 1990). Specifically for Baldwin, we used paired $t$ tests to detect significant changes between 1987 and 1997. For Esther, we used general linear models with plots as a random factor to detect significant trends between 1985, 1990, 1995, and 2000. Changes in diameter distributions were tested with Kolmogorov-Smirnov tests; changes in median height of canopy-sized trees with Mann-Whitney $U$ tests. Significant differences in RGI were defined by the nonoverlap of $95 \%$ confidence intervals based on the $t$ distribution. While we applied similar statistical analyses to the Baldwin and Esther data, it is important to note that the Baldwin plots represent a stratified random sample of the spruce-fir forest in the Baldwin watershed. Thus, the results from the Baldwin plots are representative of the entire watershed. In contrast, the Esther plots were selected to capture the range of conditions observed, and thus, inferences cannot be extrapolated beyond what is happening to the trees in these plots.

In some cases, mortality rates were based on very small sample sizes. We assessed the reliability of these estimates 
Table 1. Changes in canopy tree composition at the Baldwin site, an old-growth, spruce-fir forest on Whiteface Mountain, New York.

\begin{tabular}{lllllllr}
\hline & \multicolumn{2}{l}{ Density $(\mathrm{stem} / \mathrm{ha})$} & & \multicolumn{3}{l}{ Basal area $\left(\mathrm{m}^{2} \cdot \mathrm{ha}^{-1}\right)$} \\
\cline { 2 - 4 } \cline { 7 - 8 } Tree species & $1964-1966$ & 1987 & 1997 & & $1964-1966$ & 1987 & 1997 \\
\hline Red spruce & 253 & 154 & 148 & & 17.9 & 5.3 & 6.1 \\
Balsam fir & 521 & 612 & 657 & & 11.9 & 12.2 & 14.2 \\
Paper birch & 158 & 193 & 199 & & 7.5 & 5.1 & 6.3 \\
Yellow birch & 10 & 64 & 54 & & 1.9 & 3.4 & 3.0 \\
Total & 976 & $1068(126)$ & $1095(114)$ & & 40.3 & $26.7(2.0)$ & $30.3(2.2)$ \\
\hline
\end{tabular}

Note: Canopy trees defined as stems $\geq 9.5 \mathrm{~cm}$ DBH. The 1964-1966 data were from seven Scott stands in or near the Baldwin site. Values in parentheses are SEs $(N=11$ plots between 800 and $1100 \mathrm{~m}$ elevation).

Other tree species present and included in the total but not listed separately were Acer saccharum Marsh., Acer pensylvanicum L., Acer spicatum Lam., Sorbus americana Marsh., and Prunus pennsylvanica L.

with randomization tests based on binomial probabilities (sensu Condit et al. 1995). For 99 random samples, we developed the distribution of expected mortalities using the observed sample size and the observed ratio of surviving trees. We then took the 2.5 and $97.5 \%$ quantiles as the bounds for the $95 \%$ confidence interval for the observed mortality rate. Since the trees from the Esther plots are not intended to be population-level estimates, we did not calculate empirical confidence intervals for Esther mortality rates.

\section{Results}

\section{Community dynamics}

In the Baldwin watershed, there was no change in canopy tree $(\mathrm{DBH} \geq 9.5 \mathrm{~cm})$ density between 1987 and 1997. However, canopy tree basal area increased by $13 \%$ during the same period (Table 1; paired $t$ test, $p<0.01$ ). Paper birch experienced the largest relative increase $(24 \%)$ but the basal area of all three dominant species increased by at least $15 \%$ (Table 1). Yellow birch was the only canopy tree that declined in relative basal area during the decade. Despite this basal area increase, there were only minor changes in canopy composition. Balsam fir was the dominant species in 1987; its basal area was more than double that of spruce and paper birch. The same allocation of species dominance was true in 1997 (Table 1). The composition of the subcanopy trees was remarkably stable between 1987 and 1997 (Table 2). Also, neither the total density nor the composition of the smallest trees (trees $<5 \mathrm{~cm} \mathrm{DBH}$ and $\geq 1 \mathrm{~m}$ tall) changed at Baldwin. Both in 1987 and 1997, there were approximately 6000 stems/ha present in this size class with fir accounting for $83 \%$ of the stems; spruce, $11 \%$; and paper birch, $2 \%$.

In the Esther permanent sample plots, there were no statistically significant temporal trends in canopy tree density and basal area (repeated-measures ANOVA, $p=0.34$ for density and $p=0.71$ for basal area). However, between 1985 and 2000, there were consistent increases in the density and basal area of balsam fir coupled with consistent decreases in red spruce density and basal area (Table 3 ). Understory tree density and basal area $(2 \mathrm{~cm} \leq \mathrm{DBH}<9.5 \mathrm{~cm})$ more than doubled in the Esther plots between 1985 and 2000. Mean understory density increased from $2131 \pm 714$ (mean \pm SE) to $4418 \pm 908$ stems/ha; basal area went from $3.5 \pm 1.0$ to $8.8 \pm 2.6 \mathrm{~m}^{2} \cdot \mathrm{ha}^{-1}$. Although more than $95 \%$ of the understory trees were fir, spruce and paper birch either maintained
Table 2. Changes in subcanopy tree composition at the Baldwin site, an old-growth, spruce-fir forest on Whiteface Mountain, New York.

\begin{tabular}{lcclll}
\hline & \multicolumn{2}{c}{ Density $($ stems/ha $)$} & & \multicolumn{2}{c}{ Basal area $\left(\mathrm{m}^{2} \cdot \mathrm{ha}^{-1}\right)$} \\
\cline { 2 - 3 } \cline { 5 - 6 } Tree species & 1987 & 1997 & & 1987 & 1997 \\
\hline Red spruce & 100 & 109 & & 0.4 & 0.4 \\
Balsam fir & 736 & 742 & & 2.9 & 2.8 \\
Paper birch & 171 & 126 & & 0.7 & 0.5 \\
Yellow birch & 44 & 29 & & 0.1 & 0.1 \\
Total & $1092(246)$ & $1028(172)$ & $4.3(0.95)$ & $3.9(0.70)$
\end{tabular}

Note: Subcanopy trees are $5 \mathrm{~cm} \leq \mathrm{DBH}<9.5 \mathrm{~cm}$. Values in parentheses are SEs $(N=11$ plots between 800 and $1100 \mathrm{~m}$ elevation). Other tree species present and included in the total but not listed separately were A. saccharum, A. pensylvanicum, A. spicatum, and S. americana.

(spruce) or increased (birch) their relative abundance in the understory size class between 1985 and 2000. This general rise in understory trees contributed to net increases in basal area, density, and aboveground tree biomass in the Esther plots (Table 4). However, only the $81 \%$ increase in density was statistically detectable.

From 1987 to 1997, tree basal area and aboveground tree biomass in the Baldwin plots increased significantly with only a minor concomitant change in tree density (Table 4, Fig. 2). Also, the size distribution of trees in the Baldwin plots (based on DBH) were nearly identical between 1987 and 1997 (Fig. 2; Kolmogorov-Smirnov, $p=1.0$ ). The same was true for the diameter distributions at Esther between 1985 and 2000 (Fig. 2; Kolmogorov-Smirnov, $p=0.96$ ), although the numerical gain in total tree density at Esther was apparent.

\section{Population dynamics}

For canopy red spruce trees in Baldwin during the 10-year census interval (1987-1997), the annual mortality rate was $1.2 \% \cdot$ year $^{-1}$, and annual recruitment rate was 1.4 stems/ha per year (Table 5). The rates nearly offset each other with the net result being a small (4\%) reduction in spruce canopy tree density (Table 1). Based on the RGI, spruce grew significantly faster than associated species (Table 5). This rapid growth accounted for most of the $15 \%$ increase in spruce basal area (Table 1). For both balsam fir and paper birch, canopy recruitment exceeded mortality. Thus, a combination of recruitment and growth led to the observed increases in fir and birch basal area (Tables 1 and 5). With the exception 
Table 3. Trends in canopy tree composition at the Esther site, a high-elevation, spruce-fir forest on Whiteface Mountain, New York.

\begin{tabular}{|c|c|c|c|c|c|c|c|c|c|c|}
\hline \multirow[b]{2}{*}{ Tree species } & \multicolumn{5}{|c|}{ Density (stems/ha) } & \multicolumn{5}{|c|}{ Basal area $\left(\mathrm{m}^{2} \cdot \mathrm{ha}^{-1}\right)$} \\
\hline & 1964-1966 & 1985 & 1990 & 1995 & 2000 & 1964-1966 & 1985 & 1990 & 1995 & 2000 \\
\hline Red spruce & 356 & 81 & 65 & 59 & 57 & 15.9 & 8.1 & 6.0 & 5.0 & 4.8 \\
\hline Balsam fir & 886 & 593 & 601 & 695 & 773 & 19.1 & 14.2 & 14.4 & 16.3 & 17.2 \\
\hline Paper birch & 200 & 57 & 59 & 54 & 56 & 6.7 & 4.3 & 4.6 & 4.1 & 4.3 \\
\hline Total & 1475 & 746 (99) & 744 (119) & 826 (96) & 904 (57) & 42.1 & $26.9(1.3)$ & $25.4(1.8)$ & $25.7(2.2)$ & $26.7(2.3)$ \\
\hline
\end{tabular}

Note: Canopy trees defined as stems $\geq 9.5 \mathrm{~cm} \mathrm{DBH}$. The 1964-1966 data are from seven Scott stands in or near the Esther site. Values in parentheses are SEs $(N=4$ plots between 1000 and $1063 \mathrm{~m}$ elevation). Sorbus americana was a tree species present and included in the total but not listed separately in the table.

Table 4. Changes in forest community structure in old-growth spruce-fir sites on Whiteface Mountain, New York: (A) Baldwin and (B) Esther Mountain sites.

\begin{tabular}{lllll}
\hline (A) Baldwin site (trees $\geq 5 \mathrm{~cm} \mathrm{DBH})$. & & & & \\
\hline Parameter & 1987 & 1997 & Change $(\%)$ & $p$ \\
\hline Basal area $\left(\mathrm{m}^{2} \cdot \mathrm{ha}^{-1}\right)$ & 31.0 & 34.2 & 10 & 0.02 \\
Density $(\mathrm{stems} / \mathrm{ha})$ & 2160 & 2123 & -2 & 0.85 \\
Aboveground tree biomass $\left(\mathrm{Mg} \cdot \mathrm{ha}^{-1}\right)$ & 124 & 138 & 11 & 0.02 \\
\hline (B) Esther site $($ trees $\geq 2 \mathrm{~cm} \mathrm{DBH})$. & & & & \\
\hline Parameter & 1985 & 2000 & Change $(\%)$ & $p$ \\
\hline Basal area $\left(\mathrm{m}^{2} \cdot \mathrm{ha}^{-1}\right)$ & 30.3 & 35.6 & 17 & 0.08 \\
Density $(\mathrm{stems} / \mathrm{ha})$ & 2877 & 5328 & 81 & 0.03 \\
Aboveground tree biomass $\left(\mathrm{Mg} \cdot \mathrm{ha}^{-1}\right)$ & 107 & 115 & 8 & 0.28 \\
\hline
\end{tabular}

Note: Statistical significance was evaluated using paired $t$ tests for each structural parameter.

of yellow birch, mortality and recruitment rates of the subcanopy trees in Baldwin were higher than canopy trees (Table 6). However, there was little change in the composition of this stratum of the tree community between 1987 and 1997 (Table 2).

In contrast to Baldwin, annual mortality of red spruce canopy trees in the Esther plots consistently outpaced canopy recruitment (Table 7). For a comparable period (19851995), spruce mortality in Esther was more than double and recruitment less than $20 \%$ of the rates observed in Baldwin (Tables 5 and 7). On the other hand, while balsam fir experienced relatively high annual mortality $\left(2.0 \%\right.$.year ${ }^{-1}$ between 1985 and 1995), it had even higher rates of recruitment (24 stems/ha per year between 1985 and 1995). Balsam fir also had a significantly higher per volume growth rate than its associates (Table 7). Red spruce exhibited drastically lower relative growth rates in the Esther plots compared with Baldwin (Tables 5 and 7).

One consequence of these community and population transitions was that canopy trees at Esther have become significantly shorter. Median tree height decreased from $10.6 \mathrm{~m}$ in 1985 to $10.1 \mathrm{~m}$ in 2000 (Mann-Whitney $U$ test, $p<0.02$ ). There was no significant change in the height of the Baldwin canopy (Mann-Whitney $U$ test, $p>0.1$ ), although median canopy height did increase from $9.9 \mathrm{~m}$ in 1987 to $10.2 \mathrm{~m}$ in 1997.

\section{Discussion}

\section{Forestwide implications of spruce decline}

The recent community-level changes in these two sprucefir forests suggest that spruce decline did not initiate whole- sale transformations of tree composition and structure. We also did not find any evidence of collateral damage to balsam fir or paper birch in the wake of widespread spruce mortality (Perkins et al. 1992; McLaughlin and Percy 1999). However, there were important changes in the rate and nature of biomass accumulation since the mid-1980s. Between 1987 and 1997, the spruce-fir forest in the Baldwin watershed was an aggrading ecosystem in terms of aboveground tree biomass with the majority of the increment due to the growth of canopy-sized trees. This growth occurred with only minor shifts in composition or structure (Tables 1 and 4, Fig. 2).

Trends in the Esther plots between 1985 and 2000 included an increase in overall tree density (Fig. 2, Table 4) with most of this increase occurring in the understory size class $(9.5 \mathrm{~cm}>\mathrm{DBH} \geq 2 \mathrm{~cm})$. There was also an increase in the importance of fir relative to spruce in the canopy (Table 3). Friedland and Miller (1999) noted the importance of fir component in terms of nitrogen biogeochemistry. Nitrogen concentration in balsam fir foliage was $40 \%$ higher than red spruce. Although there was only a small increase in tree biomass between 1985 and 1995 (3\%), there was a 27\% increase in N stored in vegetation (Friedland and Miller 1999). Since 1995, the trees in the Esther plots have continued to accumulate biomass by the same means, namely an ingrowth of small fir trees.

The $0.5-\mathrm{m}$ reduction in the stature of the Esther canopy could influence population, community, and ecosystem processes at the site. For example, shorter canopy trees experience a reduced risk of mortality from both chronic and catastrophic winds (Peltola et al. 1999; Canham et al. 2001). Miller and Friedland (1999) documented the downward shift 
Fig. 2. Changes in diameter-class distributions for trees in permanent sample plots located in old-growth, spruce-fir forests on Whiteface Mountain, New York. Baldwin refers to 11 plots located in the watershed southwest of Baldwin Hill; Esther refers to the four plots located near the subpeak of Esther Mountain.
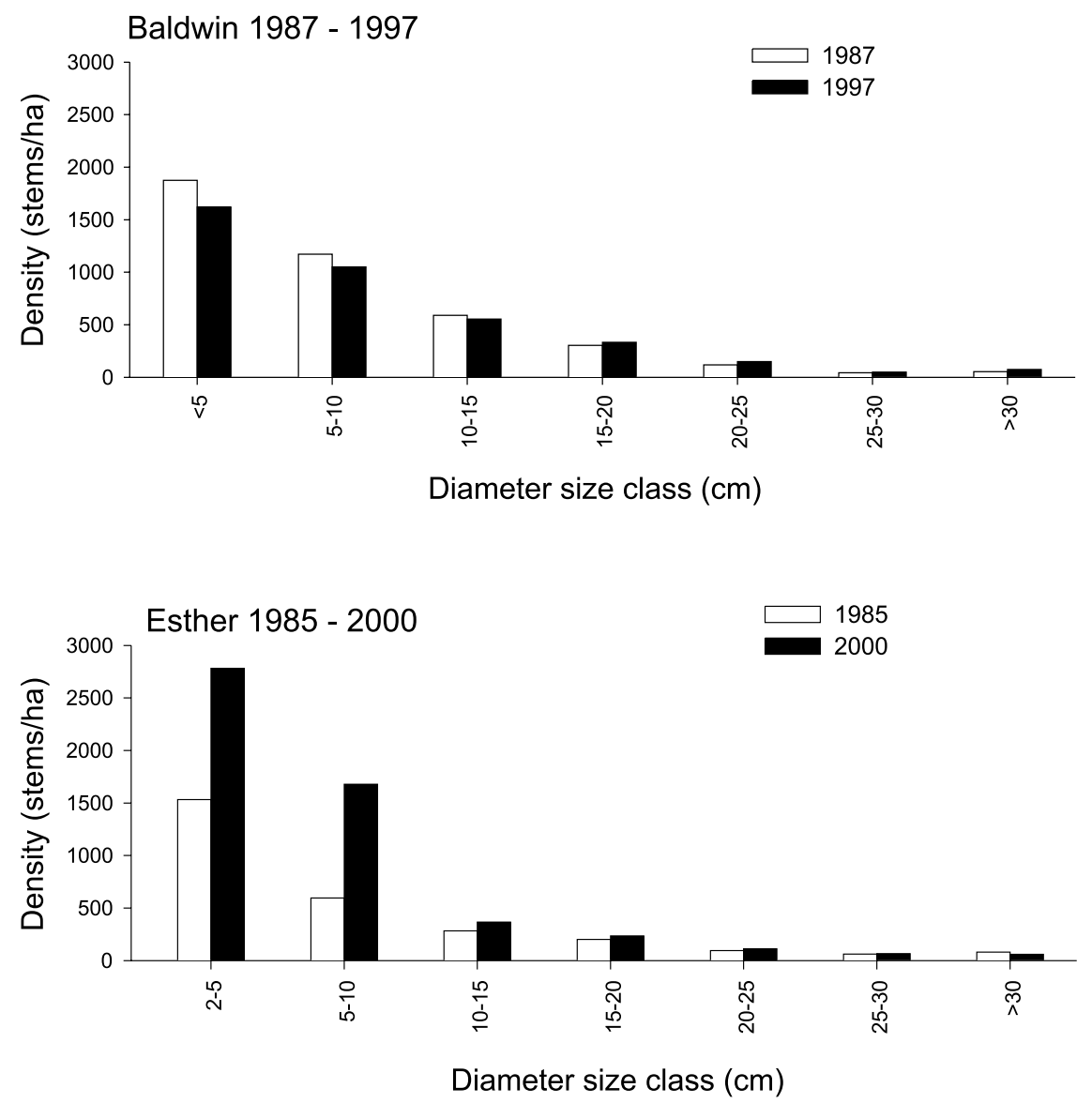

Table 5. Demography of canopy trees $(\geq 9.5 \mathrm{~cm} \mathrm{DBH})$ at the Baldwin site, an oldgrowth, spruce-fir forest, on Whiteface Mountain, New York, based on measurements of 11 permanent sample plots in 1987 and 1997.

\begin{tabular}{|c|c|c|c|c|c|}
\hline Species & $N_{0}$ & $\begin{array}{l}\text { Mortality } \\
\left(\% \cdot \text { year }^{-1}\right)\end{array}$ & $N_{\mathrm{r}}$ & $\begin{array}{l}\text { Recruitment } \\
\text { (stems/ha } \\
\text { per year) }\end{array}$ & RGI $\left(\mathrm{m}^{3} \cdot \mathrm{m}^{-3}\right)$ \\
\hline Red spruce & 69 & $1.2(0.4-2.2)$ & 6 & 1.4 & $0.113(0.074-0.152)$ \\
\hline Balsam fir & 320 & $1.6(1.1-2.0)$ & 68 & 16.5 & $0.032(0.028-0.036)$ \\
\hline Paper birch & 93 & $1.0(0.5-1.6)$ & 14 & 3.3 & $0.014(0.012-0.016)$ \\
\hline Yellow birch & 28 & $1.5(0.4-3.4)$ & 2 & 0.5 & $0.008(0.005-0.011)$ \\
\hline
\end{tabular}

Note: Elevation range was $800-1100 \mathrm{~m}$. Canopy recruitment includes correction for recruits that could have entered canopy class after 1987 but died before remeasurement in 1997 (after Sheil and May 1996). Values in parentheses are the $95 \%$ confidence intervals. $N_{0}$, number of individuals in the 1987 census; $N_{\mathrm{r}}$, number of new recruits since 1987 that were still alive in 1997; RGI, per-volume growth increment during the interval.

in the vertical distribution of leaf area associated with the changes in canopy structure in the Esther plots. In terms of the forest community, the amount of foliage in the layers available to vertebrate browsers (0-2 $\mathrm{m}$ in height) doubled from 0.6 to $1.2 \mathrm{~m}^{2} \cdot \mathrm{m}^{-2}$ between 1985 and 1995 . At the ecosystem level, any alterations in the composition and distribution of leaf area has the potential to modify the atmospheric deposition regime (Miller and Friedland 1999).

\section{Assessing recovery from decline}

Standards of proof sufficient to document the existence of a forest decline were much debated with reference to red spruce trees (e.g., Loehle 1988). Eventually a consensus was reached that relied on results from repeated censuses of relocated vegetation plots (Peart et al. 1992a). There also needs to be criteria to determine the end of a decline event and to assess the potential for recovery. Thus, we suggest that an 
Table 6. Demography of subcanopy trees $(9.5 \mathrm{~cm}>\mathrm{DBH} \geq$ $5 \mathrm{~cm})$ at the Baldwin site, an old-growth, spruce-fir forest on Whiteface Mountain, New York, based on measurements of 11 permanent sample plots in 1987 and 1997.

\begin{tabular}{lrlrc}
\hline Species & $N_{0}$ & $\begin{array}{l}\text { Mortality } \\
\left(\% \cdot \text { year }^{-1}\right)\end{array}$ & \multicolumn{1}{c}{$N_{\mathrm{r}}$} & $\begin{array}{l}\text { Recruitment } \\
\text { (stems/ha } \\
\text { per year) }\end{array}$ \\
\hline Red spruce & 43 & $3.6(2.1-5.8)$ & 39 & 9.6 \\
Balsam fir & 310 & $2.8(2.2-3.4)$ & 157 & 42.4 \\
Paper birch & 74 & $2.3(1.2-3.7)$ & 4 & 0.9 \\
Yellow birch & 15 & $0.7(0-2.2)$ & 2 & 0.5 \\
\hline
\end{tabular}

Note: Elevation range was $800-1100 \mathrm{~m}$. Canopy recruitment includes correction for recruits that could have entered canopy class after 1987 but died before remeasurement in 1997 (after Sheil and May 1996). The range of values in parentheses are the $95 \%$ confidence intervals based on 99 random samples of the binomial distribution. $N_{0}$, number of individuals in the 1987 census; $N_{r}$, number of new recruits since 1987 that were still alive in 1997.

end to the decline would require both a cessation of high mortality and a return to vigorous growth. A recovering population would need to exhibit canopy recruitment that exceeds or at least matches canopy mortality, and a regeneration rate sufficient to maintain its future presence in the community. Previously, mortality had been approximated by changes in basal area (Siccama et al. 1982; Scott et al. 1984) or percent standing dead trees (Silver et al. 1991; Battles et al. 1992). However, to get the threefold increase in standing dead spruce observed by Silver et al. (1991) from 1982 to 1987 at their Whiteface site, spruce mortality would have had to be a least $5 \% \cdot$ year $^{-1}$. The current mortality rate at Baldwin is comparable with the mortality rates reported for a stable red spruce population (i.e., nondeclining) in an oldgrowth forest in the southern Appalachians (Busing and Pauley 1994). Growth rates in the Baldwin population have also rallied to the point where red spruce was the fastest growing species in the canopy during the decade 1987-1997 (Table 5).

The case for recovery of the Baldwin spruce population is less certain. Canopy recruitment matched spruce mortality (Table 5). Overall spruce basal area increased because of the robust growth of surviving trees (Table 1). For subcanopy spruce $(5 \mathrm{~cm} \leq \mathrm{DBH}<9.5 \mathrm{~cm})$, a relatively high mortality rate $\left(3.6 \% \cdot\right.$ year $\left.^{-1}\right)$ was offset by equally high recruitment (9.6 stems/ha per year; Table 6) with the result being a small net change in subcanopy density (Table 2). The smallest size class of spruce trees (trees $\geq 1 \mathrm{~m}$ tall and $<5 \mathrm{~cm} \mathrm{DBH}$ ) remained at approximately 700 stems/ha during the sampling interval. The demographics suggest that recruitment and regeneration rates are sufficient to replace the current generation of canopy trees, but there is as yet no indication that red spruce is regaining its former status in the community. Cause for concern includes the relatively high mortality of spruce in the subcanopy size class. Given the differences in the autecology of the two conifers, spruce is expected to have lower mortality than fir in the smaller size classes (White and Cogbill 1992), yet the opposite was true for the subcanopy trees at Baldwin (Table 6).

Compared with the Baldwin population, spruce at Esther are dying faster, growing less, and recruiting more slowly
(Tables 1, 3, 5, and 7). In their analysis of element cycling at the Esther site, Friedland and Miller (1999) reported a significant decrease in red spruce basal area between 1985 and 1995. Indeed, annual spruce mortality during the interval was $3.6 \% \cdot$ year $^{-1}$, and spruce basal area decreased by $38 \%$ (Tables 3 and 7). The most recent 5-year estimate of mortality $\left(0.9 \% \cdot\right.$ year $\left.^{-1}, 1995-2000\right)$ implies a return to a more sustainable level of mortality, but this apparent reduction may be an artefact of the census-period dependence in vital rates noted by Sheil and May (1996). The evidence from the Esther plots indicates that spruce decline is not yet over.

It is important to note that the trees in the Esther plots represent a high-elevation subset of the population. In the montane forest of the U.S. Northeast, the more demanding environment encountered at higher elevations is associated with lower growth and higher mortality of the dominant tree species (Siccama 1974; Foster and Reiners 1983; Battles et al. 1992). In addition, there was a well-documented elevation gradient in the severity of spruce decline (Craig and Friedland 1991). Specifically at Whiteface Mountain, there was a significantly higher fraction of standing dead spruce above $1000 \mathrm{~m}$ in elevation (Battles et al. 1992). Also, Miller and Friedland (1999) could not detect any significant decrease in either $\mathrm{S}$ or $\mathrm{N}$ deposition rates between 1986 and 1996 at the Esther site, a result in contrast to the regionwide trend and the trend from the NADP site at a lower elevation on Whiteface Mountain. The comparison suggests that given the documented importance of the elevational complex gradient in structuring the vegetation of these mountain ecosystems (Bormann et al. 1970; White and Cogbill 1992), there most likely will be differences in the nature and timing of the forest recovery from spruce decline.

\section{Future implications}

Compared with the composition of the predecline forest (1964-1966), the contemporary forest at Baldwin and Esther had fewer spruce and a greater relative dominance of balsam fir (Tables 1 and 3). We recognize that values based on the Scott stands are biased toward larger basal area, lower tree density, and greater spruce dominance given the explicit exclusion of disturbed patches from their sample (Holway et al. 1969). Yet, these historical estimates do set an upper bound for the trajectory of any recovering stands. As of yet, none of the 15 contemporary plots were approaching the "mean" composition of the spruce-fir forest in 1964-1966.

For canopy red spruce trees at Whiteface Mountain, visual assessment of crown condition (Johnson and Siccama 1983; Silver et al. 1991; Peart et al. 1992a) has proven to be a reliable indicator of tree vigor. For the Baldwin plots, less than $5 \%$ of the spruce trees in 1987 and 1997 were in the severe crown damage class ( $>50 \%$ of crown foliage missing or discolored); for the Esther plots, more than $25 \%$ of the trees had crowns with severe damage in 1985 and 1995. The difference between sites in the proportion of trees with unhealthy crowns was reflected in the corresponding difference in spruce growth rates (Tables 5 and 7).

Looking toward the future, the return of these red spruce populations to their predecline dominance is uncertain. Weather plays a fundamental role in spruce decline. It modulates the input of the predisposing stressor (i.e., acidic de- 
Table 7. Demography of canopy trees $(\geq 9.5 \mathrm{~cm} \mathrm{DBH})$ at the Esther site, a high-elevation, spruce-fir on Whiteface Mountain, New York.

\begin{tabular}{|c|c|c|c|c|c|c|c|c|c|c|c|c|}
\hline \multirow[b]{2}{*}{ Species } & \multicolumn{3}{|c|}{ 1985-1990 } & \multicolumn{3}{|c|}{ 1990-1995 } & \multicolumn{3}{|c|}{ 1995-2000 } & \multicolumn{3}{|c|}{ 1985-1995 } \\
\hline & $N_{0}$ & $\lambda$ & $k$ & $N_{0}$ & $\lambda$ & $k$ & $N_{0}$ & $\lambda$ & $k$ & $\lambda$ & $k$ & RGI \\
\hline Red spruce & 30 & 4.5 & 0 & 24 & 2.7 & 0.5 & 22 & 0.9 & 0 & 3.6 & 0.3 & $0.028(0.021)$ \\
\hline Balsam fir & 220 & 2.5 & 17.6 & 226 & 0.8 & 26.6 & 265 & 1.9 & 25.5 & 2.0 & 23.8 & $0.306(0.033)$ \\
\hline Paper birch & 21 & 0 & 0.5 & 21 & 4.0 & 0.5 & 20 & 0 & 0.5 & 1.5 & 0.5 & $0.050(0.033)$ \\
\hline
\end{tabular}

Note: Results are from measurements of four permanent sample plots between 1000 and $1063 \mathrm{~m}$ elevation. Canopy recruitment includes correction for recruits that could have entered canopy class after 1987 but died before remeasurement in 1997 (after Sheil and May 1996). Values in parentheses are one-half the 95\% confidence interval of RGI. $\lambda$, annual mortality $\left(\% \cdot\right.$ year $\left.^{-1}\right) ; k$, recruitment (stems/ha per year). $N_{0}$, number of living trees at the beginning of the census interval; RGI, per-volume growth increment during the interval $\left(\mathrm{m}^{3} \cdot \mathrm{m}^{-3}\right)$.

position) and determines the severity of a key inciting factor (i.e., midwinter temperatures cold enough to induce freezing injury to foliage). Because of the unpredictability of the weather component of this decline, current trends that suggest an incipient recovery could be reversed by a series of cold winters.

Red spruce decline is a regional phenomenon with a complex etiology (Johnson et al. 1992). To measure and to understand any recovery will require a regionwide evaluation. Here, we present the first estimates of mortality and recruitment for the subalpine forest in the U.S. Northeast. However, many more communities and populations need to be sampled to test the spatial and temporal consistency of the trends observed for two sites on Whiteface Mountain.

\section{Acknowledgments}

We thank the New York State Department of Environmental Conservation and the Olympic Regional Development Authority for their permission to conduct long-term research on Whiteface Mountain. Douglas Wolfe from the State University of New York Atmospheric Science Research Center and Lew Staats from the Uihlein Sugar Maple Research Station graciously provided logistical help. Initial funding was provided by the USDA Forest Service Forest Response Program and the Electrical Power Research Institute. Current funding was provided by the New York and California Agricultural Research Stations and the National Science Foundation grant DEB-LTREB-00-75610. Eric Miller and Andrew Friedland generously shared their vegetation data. We thank Suzanne Wapner along with the many other people who helped with the fieldwork through the years. Comments on the initial version of this manuscript by Scott Stephens, Whendee Silver, Charles Cogbill, and two reviewers greatly improved the final version.

\section{References}

Battles, J.J., and Fahey, T.J. 1996. Spruce decline as a disturbance event in the subalpine forests of the northeastern United States. Can. J. For. Res. 26: 408-421.

Battles, J.J., and Fahey, T.J. 2000. Gap dynamics following forest decline: a case study of red spruce forests. Ecol. Appl. 10: 760-774.

Battles, J.J., Johnson, A.H., Siccama, T.G., Friedland, A.J., and Miller, E.K. 1992. Red spruce death effects on forest composition and structure on Whiteface Mountain New York. Bull. Torr. Bot. Club, 119: 418-430.
Battles, J.J., Fahey, T.J., and Harney, E.M.B. 1995. Spatial patterning in the canopy gap regime of a subalpine Abies-Picea forest in the northeastern United States. J. Veg. Sci. 6: 807-814.

Bormann, F.H., Siccama, T.G., Likens, G.E., and Whittaker, R.H. 1970. The Hubbard Brook Ecosystem Study: composition and dynamics of the tree stratum. Ecol. Monogr. 40: 373-388.

Busing, R.T., and Pauley, E.F. 1994. Mortality trends in a southern Appalachian red spruce population. Forest Ecol. Manage. 64: $41-45$.

Canham, C.D., Papaik, M.J., and Latty, E.F. 2001. Interspecific variation in susceptibility to windthrow as a function of tree size and storm severity for northern temperate tree species. Can. J. For. Res. 31: 1-10.

Cogbill, C.V., and White, P.S. 1991. The latitude-elevation relationship for spruce-fir forest and treeline along the Appalachian mountain chain. Vegetatio, 94: 153-176.

Condit, R., Hubbell, S.P., and Foster, R.B. 1995. Mortality rates of 205 neotropical tree and shrub species and the impact of a severe drought. Ecol. Monogr. 65: 419-439.

Craig, B.W., and Friedland, A.J. 1991. Spatial patterns in forest composition and standing dead red spruce in montane forest of the Adirondacks, [New York, USA] and northern Appalachians. Environ. Monit. Assess. 18: 129-144.

Cronan, C.S., and Grigal, D.F. 1995. Use of calcium/aluminum ratios as indicators of stress in forest ecosystems. J. Environ. Qual. 24: 209-226.

DeHayes, D.H., Schaberg, P.G., Hawley, G.J., and Strimbeck, G.R. 1999. Acid rain impacts on calcium nutrition and forest health. Bioscience 49: 789-800.

Driscoll, C.T., Lawrence, G.B., Bulger, A.J., Butler, T.J., Cronan, C.S., Eagar, C., Lambert, K.F., Likens, G.E., Stoddard, J.L., and Weathers, K.C. 2001. Acidic deposition in the northeastern United States: sources and inputs, ecosystem effects, and management strategies. Bioscience, 51: 180-198.

Enquist, B.J., West, G.B., Charnov, E.L., and Brown, J.H. 1999. Allometric scaling of production and life-history variation in vascular plants. Nature (London), 40: 907-911.

Fahey, T.J., Battles, J.J., and Wilson, G.F. 1998. Responses of early successional northern hardwood forests to changes in nutrient availability. Ecol. Monogr. 68: 183-212.

Fenn, M.E., Poth, M.A., Aber, J.D., Baron, J.S., Bormann, B.T., Johnson, D.W., Lemly, A.D., McNulty, S.G., Ryan, D.F., and Stottlemyer, R. 1998. Nitrogen excess in North American ecosystems: predisposing factors, ecosystem responses, and management strategies. Ecol. Appl. 8: 706-733.

Foster, J.R., and Reiners, W.A. 1983. Vegetation patterns in a virgin subalpine forest at Crawford Notch, White Mountains, New Hampshire. Bull. Torr. Bot. Club, 110: 141-153. 
Friedland, A.J., and Miller, E.K. 1999. Major-element cycling in a high-elevation Adirondack forest: patterns and changes, 19861996. Ecol. Appl. 9: 958-967.

Friedland, A.J., Gregory, R.A., Karenlampi, L., and Johnson, A.H. 1984. Winter damage to foliage as a factor in red spruce decline. Can. J. For. Res. 14: 963-965.

Friedland, A.J., Miller, E.K., Battles, J.J., and Thorne, J.F. 1991. Nitrogen deposition, distribution and cycling in a subalpine spruce-fir forest in the Adirondacks, New York, USA. Biogeochemistry 14: 31-56.

Holway, J.G., Scott, J.T., and Nicholson, S. 1969. Vegetation of the Whiteface Mountain region of the Adirondacks. In Vegetationenvironment relations at Whiteface Mountain in the Adirondacks. Edited by J.G. Holway and J.T. Scott. Atmospheric Sciences Research Center, State University of New York, Albany, N.Y. Rep. 92. pp. 1-44.

Irland, L.C. 1998. Ice storm and the forests of the Northeast: a preliminary assessment. J. For. 96: 32-40.

Johnson, A.H., and Siccama, T.G. 1983. Acid deposition and forest decline. Environ. Sci. Technol. 17: 294A-305A.

Johnson, A.H., Cook, E.R., and Siccama, T.G. 1988. Climate and red spruce growth and decline on the northern Appalachians, USA. Proc. Natl. Acad. Sci. U.S.A. 85: 5369-5373.

Johnson, A.H., McLaughlin, S.B., Adams, M.B., Cook, E.R., DeHayes, D.H., Eagar, C., Fernandez, I.J., Johnson, D.W., Kohut, R.J., Mohnen, V.A., Nicholas, N.S., Peart, D.R., Schier, G.A., and White, P.S. 1992. Synthesis and conclusions from epidemiological and mechanistic studies of red spruce decline. In Ecology and decline of red spruce in the eastern United States. Vol. 96. Edited by C. Eagar and M.B. Adams. Springer-Verlag, New York and Berlin. pp. 387-411.

Johnson, D.W., and Lindberg, S.E. 1992. Atmospheric deposition and forest nutrient cycling. Springer-Verlag, New York.

Likens, G.E., Driscoll, C.T., and Buso, D.C. 1996. Long-term effects of acid rain: response and recovery of a forest ecosystem. Science (Washington, D.C.), 272: 244-246.

Likens, G.E., Butler, T.J., and Buso, D.C. 2001. Long- and shortterm changes in sulfate deposition: effects of the 1990 Clean Air Act Amendments. Biogeochemistry, 52: 1-11.

Loehle, C. 1988. Forest decline: endogenous dynamics, tree defenses, and the elimination of spurious correlation. Vegetatio, 77: $65-78$.

McLaughlin, S., and Percy, K. 1999. Forest health in North America: some perspectives on actual and potential roles of climate and air pollution. Water Air Soil Pollut. 116: 151-197.

McNulty, S.G., Aber, J.D., and Newman, S.D. 1996. Nitrogen saturation in a high elevation New England spruce-fir stand. Forest Ecol. Manage. 84: 109-121.

Miller, E.K., and Friedland, A.J. 1999. Local climate influences on precipitation, cloud water and dry deposition to an Adirondack subalpine forest: insights from observations, 1986-1996. J. Environ. Qual. 28: 270-277.

Neter, J., Wasserman, W., and Kutner, M.H. 1990. Applied linear statistical models. Irwin, Boston, Mass.

Niklas, K.J., and Enquist, B.J. 2001. Invariant scaling relationships for interspecific plant biomass production rates and body size. Proc. Natl. Acad. Sci. U.S.A. 98: 2922-2927.

Peart, D.R., Nicholas, N.S., Zedaker, S.M., Miller-Weeks, M.M., and Siccama, T.G. 1992a. Condition and recent trends in high- elevation red spruce populations. In Ecology and decline of red spruce in the eastern United States. Vol. 96. Edited by C. Eagar and M.B. Adams. Springer-Verlag, New York and Berlin. pp. 125-191.

Peart, D.R., Poage, N.J., and Jones, M.B. 1992b. Winter injury to subalpine red spruce: influence of prior vigor and effects on subsequent growth. Can. J. For. Res. 22: 888-892.

Peltola, H., Kellomaki, S., Vaisanen, H., and Ikonen, V.P. 1999. A mechanistic model for assessing the risk of wind and snow damage to single trees and stands of Scots pine, Norway spruce, and birch. Can. J. For. Res. 29: 647-661.

Perkins, T.D., Klein, R.M., Badger, G.J., and Easter, M.J. 1992. Spruce-fir decline and gap dynamics on Camels Hump, Vermont. Can. J. For. Res. 22: 413-422.

Reams, G.A., and Van Deusen, P.C. 1995. Reply: synchronic largescale disturbances and red spruce growth decline. Can. J. For. Res. 25: 859-869.

Reiners, W.A. 1992. Twenty years of ecosystem reorganization following experimental deforestation and regrowth suppression. Ecol. Monogr. 62: 503-523.

Scott, J.T., Siccama, T.G., Johnson, A.H., and Breisch, A.R. 1984. Decline of red spruce in the Adirondacks, New York (USA). Bull. Torr. Bot. Club, 111: 438-444.

Sheil, D., and May, R.M. 1996. Mortality and recruitment rate evaluations in heterogeneous tropical forests. J. Ecol. 84: 91-100.

Shortle, W.C., and Smith, K.T. 1988. Aluminum-induced calcium deficiency syndrome in declining red spruce trees. Science (Washington, D.C.), 204: 1017-1018.

Siccama, T.G. 1974. Vegetation, soil, and climate on the Green Mountains of Vermont. Ecol. Monogr. 44: 325-349.

Siccama, T., Bliss, M., and Vogelmann, H.W. 1982. Decline of red spruce in the Green Mountains of Vermont. Bull. Torr. Bot. Club, 109: 163-168.

Siccama, T., Battles, T.J., Whitney, H., Vogelmann, H.W., Perkins, T., Hudnut, D., Johnson, A., Roy, K., Vann, D., and Williams, C. 1994a. Is the spruce decline over? Bull. Ecol. Soc. Am. 75: 211.

Siccama, T.G., Hamburg, S.P., Arthur, M.A., Yanai, R.D., Bormann, F.H., and Likens, G.E. 1994b. Corrections to allometric equations and plant tissue chemistry for Hubbard Brook Experimental Forest. Ecology, 75: 246-248.

Silver, W.L., Siccama, T.G., Johnson, C., and Johnson, A.H. 1991. Changes in red spruce populations in montane forests of the Appalachians 1982-1987 [USA]. Am. Midl. Nat. 125: 340-347.

Tobi, D.R., Wargo, P.M., and Bergdahl, D.R. 1995. Growth response of red spruce after known periods of winter injury. Can. J. For. Res. 25: 669-681.

Vann, D.R., Strimbeck, G.R., and Johnson, A.H. 1992. Effects of ambient levels of airborne chemicals on freezing resistance of red spruce foliage. For. Ecol. Manage. 51: 69-79.

White, P.S., and Cogbill, C.V. 1992. Spruce-fir forests of eastern North America. In Ecology and decline of red spruce in the eastern United States. Vol. 96. Edited by C. Eagar and M.B. Adams. Springer-Verlag, New York and Berlin. pp. 3-39.

Whittaker, R.H., Bormann, F.H., Likens, G.E., and Siccama, T.G. 1974. The Hubbard Brook Ecosystem Study: forest biomass and production. Ecol. Monogr. 44: 233-254.

Witty, J.E. 1968. Classification and distribution of soils on Whiteface Mountain, Essex County, New York. Cornell University, Ithaca, N.Y. 